\title{
COERCIVENESS AS AN INHERENT FEATURE OF JUDGE'S DISCOURSE (LINGUISTIC ASPECT)
}

\author{
Margaryta Zaitseva \\ Ph.D. in Philology, Associate Professor, Associate Professor at the Department \\ of Foreign Languages № 2, Yaroslav Mudryi National Law University of Kharkiv, Ukraine \\ e-mail: m.o.zaitseva@nlu.edu.ua, orcid.org/0000-0003-4304-3644
}

\section{Summary}

This study sheds light on the judge's discourse from the point of coerciveness. In the course of a trial, a judge forms a pattern of discursive behaviour. This pattern is fundamentally different from the patterns of discursive behaviour of other litigants. This is possible, because inter alia, the implementation of discursive behaviour is carried out with the help of specific linguistic means. Their choice is determined by the judge's pragmatic orientation for the optimal achievement of the goal in the context of social interaction. Thus, all of the above suggests that the functions performed by the discursive personality of the judge, who manifests power to exercise control over the judicial process, determine the specificity of judge`s discourse as coercive.

This piece of research has theoretical and practical value. We can stress the importance of the value of our paper in its original analysis of the speech behaviour of such discursive personalities as judge as well as analysis of the judge`s discourse as a coercive type.

Keywords: judge`s discourse, coercion, discursive personality, manifest power, metacommunitive, communicative specificity.

DOI: https://doi.org/10.23856/4420

\section{Introduction}

In different historical periods, the problem of violence has been viewed from different positions. But, as a rule, it is the problem of violence and the state, the role of the state in the implementation of violence, the justification for the use of violence. Power is realised in the discourse: «...produces things, it induces pleasure, forms knowledge, produces discourse» (Foucault, 2002, 120). The philosopher compared the process of exercising power to the process of worship, to the game, to discourse as a practice, which is also subject to certain rules, in connection with which he is interested in techniques of managing people, namely the management of their behavior (Foucault, 1984, 197).

The judge's discourse, as a particular ritualised form of power to establish the truth, combines methods of observation, qualification, classification, and punishment as a demonstration of power. Using his authority, the judge makes distinctions and passes final judgment: «...establishes over individuals a visibility through which one differentiates them and judges them» (Foucault, 1984, 197).

In the course of the judicial process, the judge constructs a model of his discursive behavior, where he uses the strategy of pressure, expressed in specific linguistic means, aimed at the optimal achievement of the goal in the conditions of social interaction. However, we did not encounter any studies devoted to the problem of coerciveness in judicial discourse in the course of the work on the article, which determined the relevance of the research. 
Thus, the aim of the paper is to establish linguistic features of coerciveness in modern Anglophone court discourse.

In order to achieve this goal, the following objectives are to be solved:

1) to clarify the terminological apparatus involved in the article;

2) to describe the communicative specificity of judge's discourse; course.

$3)$ to establish the language means expressing coerciveness in Anglophone court dis-

The aim, objectives and specificity of the material determined the choice of methods of analysis. So, during the process of investigation, the following research methods have been used: linguistic observation and analysis as well as cognitive method, pragmatic analysis method, critical discourse analysis method. In the first place, we'd like to emphasise the method of discourse analysis as it helps to investigate the language not merely as a way to convey meaning of words, but a way of achieving a certain effect.

In our choice of the methods of the analysis we were guided by the contemporary scientific paradigms: cognitive linguistics, pragmatic linguistics, speech communication theory, lexico-semantic analysis methods. Elements of cognitive analysis helped to identify the dependence of court discourse on social conditions.

To carry out our research, we selected and described the authentic language material.

\section{The notion of coerciveness}

The ancient Chinese statesman Shang Yang in the 4th century B.C. wrote the study "The Book of the Ruler of Shan State», where he linked violence as punishment and virtue: «Punishment begets strength, strength begets might, might begets greatness, which inspires awe, and greatness, which inspires awe, begets virtue. So virtue has its origin in punishment» (Shan, 1973).

The views of Thomas Aquinas are also interesting. He considers man a rational, moral and collective being who, however, «...cannot provide for himself the necessities of life if left alone...», so the power of the state in the person of the king is seen as a good, as a phenomenon of the divine order. The law, as Thomas Aquinas interprets it, must use «force and fear» to restrain those who was «found to be depraved, and prone to vice, and not easily amenable to words». So that they refrain from evil deeds, and leave others alone: «desist from evil-doing, and leave others in peace», and that this behavior becomes «habituated in this way» (Aquinas, 1920).

Immanuel Kant, in «The Doctrine of Law», views violence/coercion as a dual phenomenon: both restraining human freedom and promoting human freedom, since violence in the form of law prevents the rights of some citizens from being violated by others. Only such violence can be justified.

J. Mill (1988) believed that people must obey laws for the good of society, but that compliance with the law could only be achieved through despotic rule. In addition to restrictions imposed by the state, according to his conception, there should be restrictions by civil institutions.

The development of law and legal institutions and the development of analytical approaches to philosophy provided philosophers and legal theorists with an opportunity to define the concept of coercion in more depth. It is impossible not to pay attention in this regard to H. Kelsen's study «The Pure Doctrine of Law» (1934), where he separates jurisprudence from philosophy of justice, sociology and politics, axiological problems: «Jurisprudence is completely uncritically mixed up with psychology and sociology, ethics and political 
theory» (Kelsen, 2015, 10). The key characteristic of law is its coercion. Here is a quote: «Its hallmark is the use of coercion; this means that the act envisaged by the order as a consequence of a socially harmful action must be carried out also against the will of its recipient, and in case of resistance on his part, also with the use of physical force» (Kelsen 2015, 50). Law therefore cannot exist without power, as it is «a specific order of power or organisation of power» (Kelsen, 2015, 325).

Michel Foucault does not limit the phenomenon of power to the state and state authorities. He views the phenomenon of power as a multidimensional and multi-dimensional phenomenon, existing everywhere and inherent in everything - army, courts, politicians, family, noting that each of the institutions uses different mechanisms, technologies and methods of exercising power: «power relations are entangled in other types of relations (productive, marital, familial, and sexual), where they play both a determining and conditional role...» (Foucault, 2002, 313). In other words, «Power is everywhere not because it embraces everything, but because it emanates from everywhere» (Foucault, 1996, 193). In the same work, he defines power and understands it as «a plurality of relations of power... power is to be understood as the strategies within which these relations of power achieve their efficacy...» (Foucault, 1996, 191-192). Like any game, power is a confrontation: «...the relationship of power may become a confrontation between two adversaries...» (Foucault, 2002, 347). Whereby, speakers are assigned certain roles as well as certain rules are set.

Another contemporary researcher, Philip Pettit, also mentions the controlling role of discourse (discursive control). However, he views the problem of power from a different perspective - freedom as the absence of any kind of domination. To achieve this, and to strike a balance between power and human rights, he suggests that discursive control through persuasion. «It is only by means of international debate, grounded in the acceptance of certain common reasons, that states can hope to establish where, as in such cases, they may be harming one another and where the limits should naturally be set to the freedom as nondomination...» (Pettit, 2010, 85). Discursive control is about having the ability to engage in discussion and the ability to persuade.

Thus, the study of discourse is to some extent aimed at revealing the mechanisms of controlling the behaviour of actors, so by referring to judicial discourse as coercive, we mean identifying how the agent performing the role of coercive agent manifests itself in communicative forms.

\section{Communicative specificity of judge`s discourse}

When dealing with court documents, we have noticed that the judge's discourse is fundamentally different from the lawyer's discourse and the discourse of the prosecution. However, what accounts for its difference. We hypothesise that the discursive role of the judge in judicial discourse determines the uniqueness of judicial discourse, thereby establishing its distinctive characteristics. As we see it, it is the functions performed by the discursive person (the so-called discursive role - our term) that differentiates the judge`s discourse from other types of judicial discourse. To substantiate our point of view, let us turn to a brief characterisation of the concepts of «meta-communication» and «meta-meta-communication» in the context of trial.

Linguistics defines metacommunication as communication about communication. Here is an interesting quote: «it is communication about how communication is organised and proceeds, it is text about text, discourse about discourse, utterance about utterance» (Formanovskaya, 2012, 146). V. Devkin views metacommunication as «the service sphere of communication»: «When what is spoken about refers to the «service» sphere of communication, 
to the way the conversation is conducted and the extent to which it ensures mutual understanding, we are dealing with what is called metacommunication» (Devkin, 1981, 84).

In the context of court with its ritualism and ceremonialism, the communicative process is transformed. Thus, W. O'Barr, analysing the speech behaviour of actors in court, writes that «It is common knowledge that how something is said may be more important than what is actually said» (O'Barr, 1982, 1). In other words, the transfer of an utterance often takes precedence over the content of the utterance.

Thus, litigants have to reflect and observe not only the verbal component of communication, but also the way it is presented, which affects the communicative relationship between litigants, who must receive information, sound out information, react to information, interpret information, focus on information and influence through information as a result. In the process of communication not only the transmission and control of information takes place, but also the influence with the information, which gives grounds to treat as meta-communicative the discourse of the defence and the discourse of the prosecution. In distinguishing judge`s discourse, we proceeded from the fact that the judge receives already interpreted information from lawyers, the prosecutor, witnesses, experts, the plaintiff, the defendant. Significantly, facts of reality (communication) are so «loaded» with interpretation (metacommunication) that the original meaning is lost: «That is, the actual message (the communication) being conveyed is overwhelmed by the metacommunication, so that the original meaning is lost» (Metz, 2017). Emphasis should be placed on the fact that specialists professionally process the information a judge receives. In this complex area of information, the judge must orientate himself or herself, that is, to separate true facts from artificially transformed facts and to make a decision. In addition, the function of the judge is also to control the whole process, positioning himself as a representative of the authority empowered by the state to administer justice.

Finally, it cannot be omitted to mention that the judge also gives a valedictory speech to the jury, if they are present at the trial, in order for them to reach a verdict according to his instructions. In this case, we are talking about meta-communication. We should stress here that the jury must know what the judge thinks about the information presented before assessing it properly. As the lawyers' and prosecutor's interpretations (metacommunication) are often not sufficient for them to reach a verdict, what opinion the judge has about the arguments of the defence and prosecution, their actions in the courtroom, when he accepts or rejects the lawyer's and prosecutor's motions. «But to many people, the metacommunication isn't enough. They want to know the meta-metacommunication first. That is, they want to know what other people think of the person who delivered the message before giving the message its due» (Metz, 2017). For example, a misunderstood judge's message for various reasons - lack of authority, loss of control over the trial - can lead to a nullifying jury verdict and vice versa.

The discursive role of the judge in judicial discourse involves the following functions:

1) creating an authoritative image of the judge to organise an effective communication process;

2) regulating the communication process in order to obtain full information from the interactants of the judicial process;

3) stimulating the communication process in the courtroom in order to obtain full information from the interactants of the judicial process;

4) ensuring alteration, i.e. changing the speaker and the listener to ensure the adversarial principle;

5) exercising message comprehension control and feedback to avoid communicative failure; 
6) presenting one's point of view to focus the jury's attention challenge.

7) formulating the judgment in such a way as to exclude the possibility of its further

Thus, all of the above suggests that the functions performed by the discursive personality of the judge, who manifests power to exercise control over the legal proceedings, determine the specificity of judge's discourse as a coercive one and classify it as a meta-meta-communicative discourse.

\section{Linguistic means expressing coerciveness in judge`s discourse}

The examples given below are taken from case $14-185$ of 2014, which was heard by the US Supreme Court (Supreme Court, 14-185).

Thus, only the judge has the right to ask questions in court to any participant:

JUSTICE KENNEDY: Can you explain why...? But why that is not a crime involving moral turpitude? ... why did the Fifth Circuit treat this, therefore, as a-as it requested review the sua sponte extension granted below? Why? Why would one that?

JUSTICE GINSBURG: Would the Fifth Circuit, with this rulemaking, you can'ttell us what t is at this stage, this early stage, would it be available, will they have a rule should we remand this case to the Fifth Circuit?

CHIEF JUSTICE ROBERTS: Where... where is Mr. Mata at this point? (Supreme Court, $14-185$ ).

The judge, as the dominant discursive person, is able to make jokes in the courtroom, while other participants are limited in this regard. Moreover, jokes on their part are not considered appropriate. Here are some examples from the case cited:

JUSTICE KENNEDY: You know the way to our hearts. (Laughter.)

JUSTICE KAGAN: He's definitely Justice Scalia. (Laughter.)

JUSTICE KAGAN: And we're not often confused. (Laughter.)

JUSTICE SCALIA: It's a good question, though. (Laughter.) (Supreme Court, 14 - 185).

Judges may use expressive language:

JUSTICE GINSBURG: Can you explain why on the surface, he beats up his girlfriend (Supreme Court, $14-185$ ).

The judge may re-question (1), clarify (2) and even interrupt (3):

(1) JUSTICE SOTOMAYOR: Now, I've - I'veforgotten, but is there a circuit split on that third on the sua sponte review?;

JUSTICE KAGAN: I'm sorry, but there would be an NPR when? Late this calendar year?

(2) JUSTICE GINSBURG: What if ...;

JUSTICE KAGAN: And Mr. Yang, could you point me to the place in the board's decision that you think makes clear what the board was doing?;

JUSTICE KAGAN: So on that assumption, that would, as I understand it, give the Fifth Circuit something new to think about in - in addressing this question; is that right?

(3) MR. FLEMING: It's ...

JUSTICE SCALIA: Why... why would it have done that if it if it thought that, in fact, there was some argument;

MR. FLEMING: The ...

JUSTICE SCALIA: I thought all it did was...;

MR. FLEMING: Now, because they have not ... 
JUSTICE SCALIA: Which means there... there's no equitable tolling (Supreme Court, $14-185$ ).

All the above give grounds to assert that judge's speech is powerful one. It is characterised by the use of legal language as a tool to control, regulate, impose obligations and pass judgement: «...law uses its language as an instrument, through which people are ruled, regulated, obligated, and judged» (O'Barr, 1982, 25).

\section{Conclusions}

In the course of a trial, a judge forms a pattern of discursive behaviour. This pattern is fundamentally different from the patterns of discursive behaviour of other litigants. The implementation of discursive behaviour is carried out with the help of specific linguistic means. Their choice is determined by the judge's pragmatic orientation for the optimal achievement of the goal in the context of social interaction.

The judge's discourse, as a special ritualised form of power to establish the truth, combines methods of observation, qualification, classification, punishment as a demonstration of power. Using his or her authority, the judge makes distinctions and renders a final judgment. Thus, all of the above suggests that the functions performed by the discursive personality of the judge, who manifests power to exercise control over the judicial process, determine the specificity of judge's discourse as coercive.

This piece of research has theoretical and practical value. We can stress the importance of the value of our paper in its original analysis of the speech behaviour of such discursive personalities as judge as well as analysis of the judge`s discourse as a coercive type.

The practical value of the paper is in providing the possibility of using its provisions and conclusions, the factual material in the study of communicative science, psycholinguistics, discourse analysis, in the practice of translation, linguistics and area studies, in the course of legal writing, oratory.

It is worthwhile to bear in mind that for reasons of scope of the article, we were not able to fully cover all the issues of interest related to the manifestation of coerciveness in speech behaviour of a judge. Therefore, we would like to note that the study is promising in terms of dealing with such issues as manifestation of coerciveness in speeches of other litigants, e.g. defendants, witnesses, experts.

\section{References}

Aquinas, T. (1920). The Summa Theologica. Second and Revised Edition. Translated by Fathers of the English Dominican Province. Available at: https://www.newadvent.org/summa/

Devkin, V. (1981). Dialog: nemetskaya razgovornaya rech v sopostavlenii s russkoy [Dialogue: German colloquialism versus Russian colloquialism]. Moscow: Vysshaya shkola [in Russian]. Formanovskaya, N.I. (2012). Kommunikativnyy kontakt [Communicative Contact]. Moscow: Izdatelstvo IKAR [in Russian].

Foucault, M. (1984). The Foucault Reader. New York: Pantheon Books

Foucault, M. (1996). Volya k istine: po tu storonu znaniya. vlasti i seksualnosti. Raboty raznykh let [The Will to Truth: Beyond Knowledge, Power and Sexuality. Works from different years]. Moscow: Kastal [in Russian].

Foucault, M. (2002). Power: The Essential Works of Michel Foucault. London: Penguin Books. 
Kelsen, H. (2015). Chistoye ucheniye o prave [The Pure Doctrine of Law]. St. Petersburg: OOO Izdatelskiy Dom «Alef-Press» [in Russian]

Metz, M. (2017). Understanding Metacommunication. Available at: https://jmetz.com/2017/09/ understanding-metacommunication/.

Mill, J. (1988). Razmyshleniya o predstavitelnom pravlenii [Reflections on representative government]. Available at: https://vtoraya-literatura.com/pdf/mill_razmyshleniya_o_predstavitelnom_pravlenii_1988_ocr.pdf [in Russian].

Pettit, P. (2010). A Republican Law of Peoples. European Journal of Political Theory, 9, p. 70-94.

O'Barr, W. (1982). Linguistic Evidence. Language, Power and Strategy in the Courtroom. New York, London, Paris, San Diego, San Francisco, Sao Paulo, Sydney, Tokyo, Toronto: Academic Press.

Shang, Ya. (1973). Kniga pravitelya oblasti Shan [The Book of the Ruler of Shan]. Available at: http://library.nlu.edu.ua/POLN_TEXT/KOMPLEKS/KURS_1/kurs/10/21_1.htm [in Russian]. 